\title{
NADMIERNY FORMALIZM PROCESOWY JAKO NARUSZENIE ART. 6 UST. 1 KONWENCJI O OCHRONIE PRAW CZLOWIEKA I PODSTAWOWYCH WOLNOŚCI
}

\section{WSTĘP}

Formalizm procesowy, rozumiany jako obowiązek dokonywania czynności procesowych „w określonej formie, miejscu oraz czasie”, stanowi nieodłączną część każdego postępowania sądowego. Postępowanie całkowicie odformalizowane, nieoparte na procedurze ujętej w przepisach prawa, miałoby charakter arbitralny, a organu wydajacego rozstrzygnięcia w ten sposób z cała pewnościa nie można byłoby określić mianem „sądu” ${ }^{2}$ Z tej perspektywy procedura stanowi więc nie tyle ograniczenie prawa do sądu, ile warunek konieczny jego realizacji. Jednocześnie wiele rozwiąań proceduralnych, takich jak np. wymogi formalne pism procesowych czy terminy, może stanowić barierę w dostępie do sądu. Nie znaczy to oczywiście, że zawsze sa one niedopuszczalne - w wielu przypadkach formalizm procesowy realizuje prawnie doniosłe cele, przyczyniając się do zwiększenia efektywności postępowania czy pewności prawa ${ }^{3}$. Istnieją zarazem pewne granice, po których przekroczeniu regulacje proceduralne nie sa już uzasadnionymi mechanizmami służącymi zapewnieniu efektywności postępowania, lecz przejawem nadmiernego formalizmu procesowego, stanowiacym pogwałcenie prawa do sądu. Niniejszy artykuł stanowi próbę wyznaczenia owych granic na podstawie analizy orzecznictwa Europejskiego Trybunału Praw Człowieka (ETPC) na tle art. 6 ust. 1 Konwencji o ochronie praw człowieka i podstawowych wolności ${ }^{4}$.

${ }^{1}$ Kościółek (2020); por. Cieślak (2007).

2 Jak trafnie zauważył Wróbel (2010: 310): „Za sąd w rozumieniu art. 6 ust. 1 [EKPC - M.S.] można [...] uznać [...] tylko taki i wyłącznie taki organ, który spełnia przesłanki [...] proceduralne, a mianowicie postępowanie przed sądem jest przewidziane prawem".

${ }^{3}$ Zob. np. Zembrzuski (2018): 6-7.

${ }^{4}$ Konwencja o ochronie praw człowieka i podstawowych wolności sporządzona w Rzymie dnia 4 listopada 1950 r., Dz. U. 1993, Nr 61, poz. 284 (dalej jako: EKPC). 


\section{POJĘCIE NADMIERNEGO FORMALIZMU NA GRUNCIE EKPC}

Koncepcja zakazu nadmiernego formalizmu procesowego nie pojawia się w samym tekście EKPC, lecz została wypracowana w orzecznictwie ETPC ${ }^{5}$. Terminem tym Trybunał posługuje się w dwóch kontekstach. Po pierwsze, odwołuje się do niego podczas oceny zgodności ograniczeń prawa do sądu występujących na gruncie konkretnej sprawy z art. 6 ust. 1 EKPC. To właśnie ten aspekt zasady zakazu nadmiernego formalizmu jest głównym przedmiotem niniejszego artykułu. Omawianym tu pojęciem Trybunał posługuje się jednak także podczas badania, czy zostały dochowane przewidziane w EKPC wymogi formalne wniesienia skargi indywidualnej. W tym zakresie ETPC niejednokrotnie podkreślał, że wymóg wyczerpania wszystkich krajowych środków zaskarżenia, jako jeden z warunków dopuszczalności skargi indywidualnej, musi być interpretowany elastycznie i w sposób wolny od nadmiernego formalizmu ${ }^{6}$. Zakaz nadmiernego formalizmu wiąże zatem nie tylko państwa, ale i sam ETPC, co świadczy o doniosłym znaczeniu tej zasady.

Trybunał nigdy nie zdefiniował pojęcia nadmiernego formalizmu ${ }^{7}$. Aby skonstruować taką definicję, należy w pierwszej kolejności przypomnieć, że art. 6 ust. 1 EKPC zawiera w sobie kilka gwarancji: prawo do dostępu do sądu, prawo do sprawiedliwego i publicznego rozpatrzenia sprawy, prawo do rozpoznania sprawy w rozsądnym terminie, prawo do rozpoznania sprawy przez sad bezstronny, niezawisły i ustanowiony ustawa, a także prawo do wykonania wyroku ${ }^{8}$. Wymogi formalne prowadzą najczęściej do ograniczenia pierwszej z wymienionych gwarancji, a więc prawa do dostępu do sądu ${ }^{9}$ - przykładem może być choćby odrzucenie środka zaskarżenia wniesionego z przekroczeniem terminu ${ }^{10}$. Nie oznacza to jednak, że każda tego typu regulacja jest z gruntu podejrzana. Artykuł 6 EKPC nie ma przecież charakteru absolutnego i dopuszczalne jest poddawanie go restrykcjom, pod warunkiem że służą one realizacji uzasadnionego celu, maja charakter proporcjonalny i nie prowadza do naruszenia istoty prawa do sądu ${ }^{11}$. Wiele wymogów formalnych te kryteria spełnia, ponieważ, jak podkreśla ETPC, co do zasady „,...] przestrzeganie sformalizowanych reguł postępowania cywilnego [...] jest wartościowe i ważne, gdyż jest zdolne do ograniczenia dyskrecjonalności, zapewnienia równości bro-

${ }^{5}$ Również TK posługuje się w swoim orzecznictwie pojęciem zakazu nadmiernego formalizmu - zob. np. Pawliczak, Wach-Pawliczak (2012): 159-165.

${ }^{6}$ Zob. np. wyrok: ETPC: z 16 lipca 2019 r. w sprawie Zhdanov i inni przeciwko Rosji, skargi nr 12200/08, 35949/11 i 58282/12: pkt 111; z 2 maja 2019 r. w sprawie Pasquini przeciwko San Marino, skarga nr 50956/16: pkt 120.

7 Zob. np. Piaskowska (2018): 20.

8 Por. Hofmański, Wróbel (2010): 248-249.

9 Hofmański, Wróbel (2010): 301.

${ }_{10}$ Nadmierny formalizm może jednak prowadzić także do naruszenia innych gwarancji przewidzianych w art. 6 ust. 1 EKPC, w szczególności prawa do sprawiedliwego procesu - por. np. wyrok ETPC z 26 lipca 2018 r. w sprawie Bartaia przeciwko Gruzji, skarga nr 10978/06: pkt 34.

11 Zob. np. wyrok Wielkiej Izby ETPC z 15 marca 2018 r. w sprawie Naüt-Liman przeciwko Szwajcarii, skarga nr 51357/07: pkt 114-115. 
ni, chroni przed arbitralnościa, zapewnia skuteczne ustalenie przedmiotu sporu i możliwość rozstrzygnięcia sprawy w rozsądnym terminie, a także chroni pewność prawa i szacunek dla sądu" ${ }^{12}$. Co więcej, wprowadzenie pewnych wymogów formalnych jest wręcz konieczne, gdyż według Trybunału art. 6 ust. 1 EKPC zobowiąuje państwa do unikania nie tylko nadmiernego formalizmu procesowego, ale i „[...] nadmiernej elastyczności, która prowadziłaby do zniesienia wymogów proceduralnych ustanowionych przez prawo" ${ }^{13}$. Z nadmiernym formalizmem będziemy mieli więc do czynienia dopiero wówczas, gdy określony przepis ,[...] przestaje służyć zasadzie pewności prawa i właściwemu funkcjonowaniu wymiaru sprawiedliwości, tworząc rodzaj bariery blokującej stronie postępowania merytoryczne rozpoznanie jej sprawy przez sąd"14.

Nadmierny formalizm, w znaczeniu przyjętym przez ETPC, można byłoby więc zdefiniować jako nieproporcjonalne ograniczenie prawa do sądu polegajace na nałożeniu na jednostkę zbyt daleko idących, nieadekwatnych z punktu widzenia celu danej regulacji proceduralnej oraz okoliczności sprawy, sankcji procesowych z tytułu niedochowania pewnych wymogów formalnych, wynikających z nazbyt „sztywnej” treści przepisów krajowych lub niewłaściwego sposobu ich zastosowania. Taka definicja nie jest oczywiście w pełni precyzyjna, w związku z czym dokonanie jednoznacznej oceny, czy w danym przypadku doszło do naruszenia art. 6 ust. 1 EKPC, nie jest łatwe. Nie sposób też oprzeć się wrażeniu, że ETPC rozstrzyga zawisłe przed nim sprawy na zasadzie a casu ad casum, nie formułując jednoznacznych tez mogacych przyczynić się do ukształtowania stabilnej linii orzeczniczej.

Niemniej na podstawie analizy orzecznictwa Trybunału można wskazać najważniejsze czynniki brane pod uwagę podczas dokonywania oceny, czy zastosowanie określonej sankcji procesowej z tytułu niedochowania przez stronę postępowania wymogów formalnych stanowi przejaw nadmiernego formalizmu. Po pierwsze, istotne jest to, czy dany wymóg formalny, stanowiący barierę w dostępie do sądu, ma podstawę w prawie krajowym, a jeśli tak, to czy prawo to zostało w odpowiedni sposób skonstruowane. Po drugie, należy uwzględnić sposób zastosowania danego przepisu w realiach konkretnej sprawy.

\section{NADMIERNY FORMALIZM WYNIKAJĄCY Z TREŚCI PRZEPISÓW KRAJOWYCH LUB ICH BRAKU}

Wymogi formalne powinny mieć jasną podstawę w prawie krajowym. W sytuacji gdy takiej podstawy brakuje, nakładanie na jednostki sankcji procesowych wyłącznie na podstawie dokonanej przez sąd „twórczej” wykładni na niekorzyść strony postępowania może zostać uznane za przejaw niedopusz-

${ }_{12}$ Wyrok Wielkiej Izby ETPC z 5 kwietnia 2018 r. w sprawie Zubac przeciwko Chorwacji, skarga nr 40160/12: pkt 96 (tłum. własne).

${ }^{13}$ Wyrok ETPC z 11 października 2018 r. w sprawie Parol przeciwko Polsce, skarga nr 65379/13: pkt 38 (tłum. Ministerstwo Sprawiedliwości).

${ }^{14}$ Zubac przeciwko Chorwacji: pkt 98 (tłum. własne). 
czalnego nadmiernego formalizmu. W tym zakresie warto zwrócić uwagę na wyrok ETPC w sprawie Poirot przeciwko Francji ${ }^{15}$. Skarżąca, pokrzywdzona działająca w postępowaniu karnym jako powód cywilny, złożyła do sądu zażalenie na postanowienie sędziego śledczego o zmianie kwalifikacji czynu zarzucanego oskarżonemu. Zażalenie zostało jednak odrzucone, gdyż zdaniem sądu karnego skarżąca nie wskazała, zgodnie z jaką podstawą prawną wnosi środek zaskarżenia. Rozpatrując skargę, ETPC zwrócił uwagę, że francuskie prawo wcale nie przewidywało expressis verbis obowiązu wskazania podstawy prawnej zażalenia. Sądy krajowe mogą oczywiście interpretować przepisy, w tym przypadku jednak wykładnia ta była nadmiernie formalistyczna. Było bowiem jasne, jaka jest podstawa prawna zażalenia, gdyż mógł ją stanowić wyłącznie jeden przepis kodeksu. Wykładnia przyjęta przez sądy miała także dolegliwe skutki dla skarżącej, ponieważ decyzja o odrzuceniu zażalenia nie podlegała zaskarżeniu ${ }^{16}$.

Samo istnienie podstawy prawnej nie jest jednak wystarczajace do zapewnienia stanu zgodności z art. 6 ust. 1 EKPC. Wymóg formalny ograniczający prawo do sądu musi być także przewidywalny, co oznacza, że przepisy go ustanawiające powinny być jasne oraz interpretowane przez organy krajowe w sposób przewidywalny i spójny ${ }^{17}$. Interesującego przykładu naruszeń standardów konwencyjnych w tym zakresie dostarczają dwie sprawy: Zvolský i Zvolská przeciwko Czechom $^{18}$ oraz Běleš $i$ inni przeciwko Czechom $^{19}$. Obie dotyczyły interpretacji przepisów, w świetle których jednym z warunków dopuszczalności skargi konstytucyjnej było uprzednie wyczerpanie wszystkich środków zaskarżenia. Nie było jednak jasne, czy wyczerpać należało także nadzwyczajny środek zaskarżenia w postaci skargi kasacyjnej, zwłaszcza biorąc pod uwagę, że Sądowi Najwyższemu Czech przysługiwała znacząca swoboda przy podejmowaniu decyzji w przedmiocie przyjęcia go do rozpoznania. W pierwszej ze spraw skarżący złożyli skargę kasacyjna, ale sąd ten nie przyjął jej. W tej sytuacji Sąd Konstytucyjny odrzucił ich skargę konstytucyjną z powodu wniesienia jej po terminie - uznał bowiem, że skoro skarga kasacyjna okazała się niedopuszczalna, znaczy to, że ze skargą konstytucyjną należało wystapić już po wyroku sądu drugiej instancji. Sprawa Běleš $i$ inni dotyczyła sytuacji niejako odwrotnej - w tym przypadku skargi konstytucyjne zostały odrzucone z powodu niezłożenia skargi kasacyjnej. W obu orzeczeniach ETPC stwierdził naruszenie art. 6 ust. 1 EKPC, m.in. uwagi ze względu na stan niepewności prawnej, w jakim skarżący zostali postawieniu wskutek wadliwej konstrukcji przepisów.

${ }^{15}$ Wyrok ETPC z 15 grudnia 2011 r. w sprawie Poirot przeciwko Francji, skarga nr 29938/07.

${ }_{16}$ Podobnie zob. np. wyrok ETPC z 5 grudnia 2013 r. w sprawie Omerović przeciwko Chorwacji (nr 2), skarga nr 22980/09: pkt 42-47.

${ }^{17}$ Wyrok ETPC z 11 lutego 2014 r. w sprawie Maširević przeciwko Serbii, skarga nr 30671/08: pkt 50 (tłum. własne).

${ }^{18}$ Wyrok ETPC z 12 listopada 2002 r. w sprawie Zvolský i Zvolská przeciwko Czechom, skarga nr 46129/99.

${ }^{19}$ Wyrok ETPC z 12 listopada 2002 r. w sprawie Běleš $i$ inni przeciwko Czechom, skarga nr 47273/99. 
Należy wreszcie odnotować, że nawet względnie jasne i precyzyjne przepisy moga prowadzić do naruszenia zakazu nadmiernego formalizmu, jeśli ustanawiają zbyt daleko idace i obwarowane nadmiernie surowymi sankcjami wymogi formalne. Przykładowo, sprawa Fatma Nur Erten i Adnan Erten przeciwko Turcji $i^{20}$ dotyczyła przepisu wyłączającego możliwość zmiany kwoty dochodzonej tytułem odszkodowania w postępowaniu przed sądami wojskowymi. Skarżący początkowo zażądali sumy stanowiącej równowartość 250 euro jako rekompensatę za straty materialne związane ze śmiercią ich syna. W toku postępowania biegli ocenili jednak szkodę powodów na ponad 21 tys. euro. Skarżący wnieśli o zmianę dochodzonej kwoty, sąd jednak uznał to za niedopuszczalne i zasądził na ich rzecz sumę wskazaną w pozwie. W ocenie ETPC takie przepisy krajowe były nadmiernie formalistyczne. Powodowie mogli bowiem nie być w stanie precyzyjnie ustalić wysokości doznanej przez siebie szkody na etapie sporządzania pozwu i uzyskać wiedzę w tym zakresie dopiero po zapoznaniu się z opinią biegłych. Nadmierny formalizm wynikający z nieracjonalnej konstrukcji przepisów może być także związany ze zbyt krótkimi terminami na wniesienie środka zaskarżenia ${ }^{21}$ lub przyjęciem nieracjonalnego momentu rozpoczęcia biegu terminu ${ }^{22}$. Oceniając proporcjonalność danego ograniczenia prawa do sądu, należy jednak pamiętać, że w świetle orzecznictwa ETPC w postępowaniach przed sądami najwyższymi i konstytucyjnymi mogą obowiązywać szczególne, dalej idące wymogi procesowe. Jest tak - po pierwsze - dlatego, że ewentualne zamknięcie jednostce dostępu do takich organów następuje zazwyczaj już po uprzednim merytorycznym rozpoznaniu sprawy w dwóch instancjach ${ }^{23}$, a po drugie - sądy te realizują szczególne funkcje, związane z czuwaniem nad jednolitością orzecznictwa ${ }^{24}$ czy staniem na straży praworządności ${ }^{25}$. Z tego też względu w postępowaniach przed takimi organami mogą obowiązywać dodatkowe wymogi formalne służące realizacji owych szczególnych zadań.

Powyższą tezę ilustruje między innymi wyrok w sprawie Trevisanato przeciwko Włochom. Trybunał orzekł w nim, że odrzucenie kasacji przez włoski Sąd Kasacyjny ze względu na niewskazanie przez skarżacego istotnego zagadnienia prawnego nie stanowiło nadmiernego formalizmu, gdyż wymóg taki służył uzasadnionemu celowi: umożliwiał Sądowi Kasacyjnemu realizację jego ustrojowej funkcji w postaci czuwania nad jednolitością wykładni przepisów, a do tego nie był nadmiernie uciążliwy dla stron i miał oparcie w jednolicie

${ }^{20}$ Wyrok ETPC z 25 listopada 2014 r. w sprawie Fatma Nur Erten i Adnan Erten przeciwko Turcji, skarga nr 14674/11.

${ }_{21}$ Wyrok ETPC z 28 października 1998 r. w sprawie Pérez de Rada Cavanilles przeciwko Hiszpanii, skarga nr 28090/95.

${ }^{22}$ Wyrok ETPC z 25 stycznia 2000 r. w sprawie Miragall Escolano $i$ inni przeciwko Hiszpanii, skargi nr 38366/97, 38688/97, 40777/98, 40843/98, 41015/98, 41400/98, 41446/98, 41484/98, 41487/98 i 41509/98.

${ }^{23}$ Zob. np. Parol przeciwko Polsce; wyrok ETPC z 16 listopada 2000 r. w sprawie Sotiris $i$ Nikos Koutras ATTEE przeciwko Grecji, skarga nr 39442/98: pkt 22; Poirot przeciwko Francji: pkt 45.

${ }_{24}$ Zob. np. wyrok ETPC z 15.09.2016 w sprawie Trevisanato przeciwko Włochom, skarga nr 32610/07, pkt 36.

25 Zob. np. Zubac przeciwko Chorwacji: pkt 122. 
interpretowanych przepisach prawa. Oczywiście, jeśli nadzwyczajny środek zaskarżenia zostanie odrzucony bez wyraźnej podstawy prawnej czy też na podstawie przepisów (lub ich wykładni) niesłużących realizacji żadnego uzasadnionego celu, w dalszym ciagu może dojść do naruszenia EKPC. Na przykład w sprawie Bulena przeciwko Czechom ${ }^{26}$ skarżący złożył skargę do Sądu Konstytucyjnego, określając jako przedmiot zaskarżenia orzeczenie sądu pierwszej instancji utrzymane w mocy przez sąd drugiej instancji. Sąd odrzucił skargę, uzasadniając, że należało zaskarżyć orzeczenie drugiej instancji. Europejski Trybunał Praw Człowieka uznał, że takie podejście było nadmiernie formalistyczne, gdyż ze sposobu sformułowania skargi jasno wynikało, że skarżący dążył do kontroli obu orzeczeń.

Wreszcie, w pewnym zakresie na ocenę proporcjonalności ograniczenia prawa do sądu może wpływać także rodzaj postępowania. W sprawie Siwiec przeciwko Polsce ETPC zauważył bowiem, że „[...] w pewnych rodzajach postępowania cywilnego strony zobowiązane są do działania w taki sposób, by skrócić okres konieczny do przeprowadzenia dowodu oraz, że w sprawach gospodarczym takie wymogi proceduralne mogą być uzasadniane koniecznością gromadzenia niezbędnego materiału dowodowego oraz wydania rozstrzygnięcia co do meritum sprawy w jak najkrótszym czasie"27. Za tego rodzaju uzasadniony wymóg proceduralny Trybunał uznał w tej sprawie zasadę prekluzji dowodowej obowiązująca w postępowaniu w sprawach gospodarczych.

\section{NADMIERNY FORMALIZM WYNIKAJĄCY Z NIEWŁAŚCIWEGO ZASTOSOWANIA PRZEPISU}

Naruszenie EKPC może jednak wynikać nie tylko z niewłaściwego brzmienia przepisów lub ich braku, ale i sposobu ich zastosowania. Może się bowiem zdarzyć, że przepis, który sam w sobie nie narusza Konwencji, zostanie zastosowany w taki sposób, że doprowadzi w praktyce do naruszenia zakazu nadmiernego formalizmu ${ }^{28}$.

Tezę tę dobrze ilustruje wyrok ETPC w sprawie Witkowski przeciwko Polsce $^{29}$. Skarżący złożył wniosek o sporządzenie i doręczenie uzasadnienia wyroku zapadłego w prowadzonym przeciwko niemu postępowaniu karnym na godzinę przed jego ogłoszeniem. Po upływie około tygodnia wniosek ten został przez sąd uznany za nieskuteczny z uwagi na jego przedwczesność w chwili jego złożenia nie istniał jeszcze bowiem wyrok, który miał zostać

${ }^{26}$ Wyrok ETPC z 20 kwietnia 2004 r. w sprawie Bulena przeciwko Czechom, skarga nr 57567/00; zob. też wyrok ETPC z 18 października 2016 r. w sprawie Miessen przeciwko Belgii, skarga $\mathrm{nr} 31517 / 12$.

${ }^{27}$ Wyrok ETPC z 3 lipca 2012 r. w sprawie Siwiec przeciwko Polsce, skarga nr 28095/08: pkt 51 (tłum. Ministerstwo Sprawiedliwości); por. Parol przeciwko Polsce: pkt 50.

${ }^{28}$ Por. Piaskowska (2018): 21.

${ }^{29}$ Wyrok ETPC z 13 grudnia 2018 r. w sprawie Witkowski przeciwko Polsce, skarga nr 21497/14. 
uzasadniony. Postanowienie sądu w tym zakresie doręczono skarżącemu dopiero po kilku tygodniach, przez co nie mógł on już ponownie złożyć wniosku ani wnieść apelacji. Rozpoznając sprawę, ETPC podkreślił, że nie neguje zasadności terminu na złożenie wniosku o sporządzenie i doręczenie uzasadnienia wyroku. W tej konkretnej sprawie zastosowanie przepisów odbyło się jednak z naruszeniem EKPC. Po pierwsze, ETPC zauważył, że Kodeks postępowania karnego nie stanowi expressis verbis, że wniosek może być złożony dopiero po ogłoszeniu wyroku. Także orzecznictwo sądów nie było w tym zakresie jednolite ${ }^{30}$. Ponadto choć wniosek rzeczywiście został złożony przed wydaniem wyroku, to jednak do obu zdarzeń doszło w tym samym dniu. Trybunał negatywnie ocenił też działanie sądów polskich, które jego zdaniem zamiast odmawiać przyjęcia wniosku, i to dopiero po kilku dniach od jego złożenia, powinny po prostu zwrócić się do skarżącego o podtrzymanie go. W takiej sytuacji wymóg formalny przestał „służyć pewności prawa i należytemu sprawowaniu wymiaru sprawiedliwości” i przekształcił się w „swoista przeszkodę, która pozbawiła skarżącego możliwości rozpoznania jego sprawy przez sąd odwoławczy"31.

Przykładu teoretycznie racjonalnego wymogu formalnego, który utracił swe uzasadnienie wskutek nadmiernie formalistycznej interpretacji, dostarcza także wyrok w sprawie Nowiński przeciwko Polsce ${ }^{32}$. Skarżący został wezwany przez sąd do uzupełnienia braków formalnych pozwu przez wskazanie swojego miejsca zamieszkania. W odpowiedzi poinformował, że nie posiada stałego miejsca zamieszkania, gdyż po rozwodzie musiał się wyprowadzić i wymeldować z mieszkania, które uprzednio zajmował. Od tego czasu przebywał u znajomych pod różnymi adresami. Jednocześnie jednak podał skrytke pocztowa, do której należało kierować korespondencję, i zaznaczył, że jest dostępny codziennie pod adresem miejsca pracy. Sąd zarządził zwrot pozwu stwierdzając, że ani skrytka pocztowa, ani miejsce zatrudnienia nie mogą zostać uznane za miejsce zamieszkania w rozumieniu art. $126 \S 2$ Kodeksu postępowania cywilnego. Trybunał nie miał jednak wątpliwości, że w sprawie doszło do naruszenia art. 6 ust. 1 EKPC. Choć bowiem wymóg wskazania w pozwie miejsca zamieszkania jest uzasadniony, to jednak jego zastosowanie w tym przypadku doprowadziło do nieproporcjonalnego ograniczenia prawa do sądu. Skarżący nie podał stałego miejsca zamieszkania, gdyż w tamtym czasie po prostu go nie posiadał, ale mimo to pozostawał w stałym kontakcie z sądem. Nie wykazano też, że „adres dostarczony przez skarżącego nie był wystarczający w celu zapewnienia prawidłowej obsługi korespondencji sądowej lub mógł w jakikolwiek inny sposób zakłócić funkcjonowanie wymiaru sprawiedliwości”33.

30 Podobny problem może występować także na gruncie procedury cywilnej, a w tym zakresie orzecznictwo SN zostało ujednolicone uchwałą trzech sędziów z 24 maja 2017 r., III CZP 18/17, zgodnie z którą „Wniosek o sporządzenie i doręczenie uzasadnienia wyroku złożony w dniu jego ogłoszenia, lecz przed dokonaniem ogłoszenia, jest nieskuteczny”.

31 Witkowski przeciwko Polsce: pkt 56 (tłum. Ministerstwo Sprawiedliwości).

32 Wyrok ETPC z 20 października 2009 r. w sprawie Nowiński przeciwko Polsce, skarga nr 25924/06.

${ }^{33}$ Nowiński przeciwko Polsce: pkt 34 (tłum. Ministerstwo Sprawiedliwości). 
Oceny, czy w danym przypadku zastosowanie przez sąd określonego przepisu nakładającego na stronę jakąś sankcję procesową stanowiło przejaw nadmiernego formalizmu, należy dokonywać z uwzględnieniem wszystkich istotnych okoliczności sprawy ${ }^{34}$. Szczególnie ważne są tu zachowanie strony i jej cechy osobiste. Niekiedy bowiem, pomimo niedochowania określonych wymogów procesowych, stronie nie sposób postawić zarzutu niedbałości ${ }^{35}$, a jej zachowanie można uznać za usprawiedliwione. Zignorowanie przez sąd takich okoliczności może doprowadzić do niezgodnego z EKPC nadmiernego formalizmu procesowego.

Taka sytuacja występuje - po pierwsze - wtedy, gdy stronę obarczono skutkami błędów formalnych, za które nie ponosi ona winy ${ }^{36}$. W tym kontekście warto zwrócić uwagę na wyrok ETPC w sprawie Sotiris i Nikos Koutras Attee przeciwko Grecji ${ }^{37}$. Skarżąca spółka ubiegała się o dofinansowanie przez państwo pewnej inwestycji, jednakże Minister Gospodarki Narodowej wydał decyzję o odmowie uwzględnienia jej wniosku. Od decyzji tej przysługiwała skarga do Naczelnego Sądu Administracyjnego. Co istotne, dopuszczalne było złożenie skargi w siedzibie innego organu władzy publicznej, który był następnie zobowiązany do przekazania jej do NSA. Spółka złożyła więc skargę na komisariacie policji. Niestety funkcjonariusze policji nie dopełnili wszystkich formalności związanych $\mathrm{z}$ rejestracją skargi. Na tej podstawie sąd odrzucił skargę, uznając, że nie została ona prawidłowo wniesiona. ETPC uznał, że odrzucenie skargi było przejawem nadmiernego formalizmu i naruszało art. 6 ust. 1 EKPC. Niedopuszczalne jest bowiem karanie spółki za błąd, którego sama nie popełniła. Skoro w świetle prawa skarga mogła być złożona do organu władzy, to dochowanie formalności zwiąanych z jej rejestracją i przekazaniem do sądu było obowiązkiem funkcjonariuszy ${ }^{38}$.

Bardziej skomplikowane są sytuacje, w których określony błąd proceduralny był wynikiem zarówno działań strony, jak i sądu, co może nastapić na przykład wówczas, gdy sąd z naruszeniem przepisów uzna za skuteczną określoną czynność procesową dokonaną niezgodnie z prawem. Takiego właśnie przypadku dotyczył wyrok Wielkiej Izby ETPC w sprawie Zubac przeciwko Chorwacji. Skarżąca wniosła pozew, w którym określiła wartość przedmiotu sporu na 10 tys. kun. W toku postępowania, po trzech latach od złożenia pozwu, pełnomocnik skarżącej poinformował sąd, że wartość przedmiotu sporu została określona za nisko i powinna wynosić 105 tys. kun. Sądy uznały tę zmianę za skuteczna, uwzględniając nową kwotę między innymi przy ustalaniu kosztów postępowania. Po przegranej w dwóch instancjach skarżąca złoży-

${ }_{34}$ Zubac przeciwko Chorwacji: pkt 98.

${ }_{35}$ Por. np. wyrok ETPC z 28 października 1998 r. w sprawie Pérez De Rada Cavanilles przeciwko Hiszpanii, skarga nr 28090/95: pkt 47-50.

36 Zob. np. Zubac przeciwko Chorwacji: pkt 90-95.

37 Sotiris i Nikos Koutras ATTEE przeciwko Grecji.

${ }^{38}$ Za stwierdzeniem naruszenia EKPC przemawiały także inne okoliczności, m.in. fakt, że NSA działał tu jako organ I i II instancji oraz że informacja na temat numeru, pod jakim skarga została zarejestrowana, a której brakowało na pieczątce (rzekomy brak formalny), została podana na pierwszej stronie skargi. 
ła skargę kasacyjną do Sądu Najwyższego, ale została ona odrzucona ze względu na zbyt niską wartość przedmiotu zaskarżenia. Zdaniem sądu bowiem podwyższenie wartości przedmiotu sporu było niedopuszczalne, gdyż zgodnie $\mathrm{z}$ prawem chorwackim modyfikacja w toku postępowania kwoty wskazanej w pozwie jest niemożliwa bez jednoczesnego rozszerzenia zakresu powództwa. Sąd może wprawdzie zweryfikować wartość przedmiotu sporu wskazaną w pozwie, ale najpóźniej na pierwszej rozprawie, przed wdaniem się przez pozwanego w spór co do istoty sprawy. ETPC orzekł, że w sprawie nie doszło do naruszenia art. 6 ust. 1 EKPC. Podejmując decyzję o dopuszczalności nadzwyczajnego środka zaskarżenia, SN nie może być związany błędami sądów niższych instancji. W przeciwnym razie efektywność jego działania mogłaby być znacząco osłabiona. Co więcej, naprawiając błędy sądów niższych instancji, SN przywrócił praworządność, będącą fundamentem demokratycznego państwa i EKPC. Podobnie strona nie może wywodzić ekspektatyw z błędów popełnionych przez sądy, które zaakceptowały skutki jej działania niezgodnego z przepisami. Na rozstrzygnięcie Trybunału wpłynęły także i inne okoliczności sprawy, między innymi fakt, że skarżąca była reprezentowana przez profesjonalnego pełnomocnika oraz że mogła dokonać korekty wartości przedmiotu sporu przed pierwszą rozprawa. Podobnego typu błędu, lecz popełnionego w zupełnie innym stanie faktycznym, dotyczyła sprawa Skalbaniok przeciwko Polsce ${ }^{39}$. W tym przypadku sąd oddalił powództwo skarżącego, w związku z czym wystapił on o sporządzenie i doręczenie uzasadnienia wyroku. Wniosek w tym zakresie skierował jednak nie za pośrednictwem Poczty Polskiej, lecz firmy InPost. Po otrzymaniu wyroku skarżący zaskarżył go w drodze apelacji. Sąd odwoławczy odrzucił jednak środek zaskarżenia, uznając, że został on wniesiony po terminie. Skoro bowiem skarżący złożył wniosek o uzasadnienie za pośrednictwem prywatnego operatora, to należało uznać, że data wniesienia pisma nie była data złożenia wniosku u operatora, lecz doręczenia go do sądu, co nastapiło po upływie tygodniowego terminu, o którym mowa w art. $328 \S 1$ k.p.c. Wniosek o uzasadnienie był więc nieskuteczny, przez co termin na wniesienie apelacji, zdaniem sądu drugiej instancji, musiał być ustalony zgodnie z ówczesnym art. $369 \S 2$ k.p.c. i wynosił trzy tygodnie od dnia ogłoszenia sentencji. Teoretycznie również w tej sprawie doszło do „naprawienia” przez sąd wyższej instancji błędu popełnionego przez sąd niższej instancji. Zachodziły jednak okoliczności szczególne, które mogły uzasadniać wniosek, że odrzucenie apelacji było nadmiernie formalistyczne: skarżący nie był reprezentowany przez profesjonalnego pełnomocnika, nie został pouczony o skutkach wniesienia pisma w placówce operatora innego niż Poczta Polska, a jego pozew został rozpoznany tylko przez sąd jednej instancji. Prawdopodobnie właśnie ze względu na tę specyfikę rząd nie kwestionował faktu naruszenia EKPC i zdecydował się na zawarcie ze skarżącym ugody.

Niezwykle istotną okolicznością braną pod uwage przez Trybunał jest to, czy skarżący „zachował zwykle wymaganą od strony postępowania cywilnego

39 Postanowienie ETPC z 20 lutego 2018 r. w sprawie Skalbaniok przeciwko Polsce, skarga nr 26268/16. 
staranność" ${ }^{40}$. Znaczenie tego kryterium dobrze ilustruje zestawienie wyroków ETPC w dwóch sprawach polskich: Parol przeciwko Polsce ${ }^{41}$ oraz Kunert przeciwko Polsce ${ }^{42}$. Obie dotyczyły podobnego problemu - odrzucenia przez sądy krajowe apelacji powodów osadzonych w zakładzie karnym z powodu niezałączenia wymaganych odpisów. W obu przypadkach skarżący mieli trudności z uzupełnieniem braku formalnego, ponieważ nie dysponowali żadna kopią apelacji. Mimo tych podobieństw ETPC stwierdził naruszenie art. 6 ust. 1 EKPC tylko w pierwszej ze spraw. Tym, co zaważyło na różnych rozstrzygnięciach, była właśnie odmienna postawa skarżących w toku postępowania. W sprawie Parol przeciwko Polsce powód po wezwaniu do uzupełnienia braków formalnych podjął działania w celu wywiązania się z tego obowiązku: zwrócił się do sądu o nadesłanie mu, na jego koszt, kopii apelacji, a gdy to nie nastapiło, odwzorował apelację z pamięci i taki właśnie „odpis” przesłał sąowi. Tymczasem w sprawie Kunert przeciwko Polsce powód jedynie poinformował sąd, że nie jest w stanie przedłożyć odpisu, gdyż nie dysponuje kopia apelacji ani nie pamięta dokładnie jej treści. Dla ETPC znaczenie miało także to, że w przeciwieństwie do skarżącego w pierwszej ze spraw, skarżący w sprawie Kunert przeciwko Polsce został na wcześniejszym etapie postępowania pouczony o konieczności wnoszenia wszystkich pism procesowych w odpowiedniej liczbie egzemplarzy. Tym bardziej więc jego zachowanie nie mogło zostać uznane za usprawiedliwione.

Jak wskazał ETPC w wyroku w sprawie Gakharia przeciwko Gruzji ${ }^{43}$, zasada proporcjonalności wyklucza jednak stosowanie zbyt daleko idacych, nieadekwatnych sankcji procesowych nawet wobec takich jednostek, które nie dochowały w pełni należytej staranności w postępowaniu. Skarżącym był w tym przypadku mężczyzna, wobec którego wydano dwa wyroki zaoczne w przedmiocie ograniczenia jego władzy rodzicielskiej nad córka. Orzeczenia te zostały wydane po tym, jak trzykrotnie nie udało się doręczyć skarżącemu powiadomienia o terminie rozprawy na adres zameldowania oraz zamieszczono informację na temat toczącego się postępowania w gazecie. Po kilku latach skarżący wniósł o uchylenie wyroków zaocznych wskazując, że nie był świadom ich istnienia, gdyż przebywał wówczas w Rosji. Sądy obu instancji oddaliły jednak ten wniosek, wskazując w uzasadnieniu, że dochowano wszelkich formalności związanych z doręczeniami. Rozpatrując skargę mężczyzny, ETPC przypomniał, że art. 6 ust. 1 EKPC nie zabrania państwom posługiwania się instytucją wyroków zaocznych, niemniej nie może się to odbywać z pogwałceniem podstawowych standardów rzetelnego procesu. Odnosząc te standardy do sprawy skarżącego, ETPC wyraził wątpliwość, czy sposób doręczeń przyjęty przez sądy gruzińskie był wystarczający do zapewnienia, że mężczyzna zostanie skutecznie poinformowany o toczącym się postępowaniu. $\mathrm{Z}$ akt postępowania wynikało bowiem, że do sądów rozpoznających sprawę

${ }^{40}$ Parol przeciwko Polsce: pkt 47 (tłum. Ministerstwo Sprawiedliwości).

${ }^{41}$ Parol przeciwko Polsce.

${ }^{42}$ Wyrok ETPC z 4 kwietnia 2019 r. w sprawie Kunert przeciwko Polsce, skarga nr 8981/14.

${ }^{43}$ Wyrok ETPC z 17 stycznia 2017 r. w sprawie Gakharia przeciwko Gruzji, skarga nr 30459/13: pkt 50. 
skarżącego docierały informacje o jego możliwym pobycie w Rosji. Należało zatem podjaćc działania w celu ustalenia rzeczywistego adresu skarżącego, co byłoby tym łatwiejsze, że adres ten znała była żona skarżącego (druga strona postępowania). Mimo to $\mathrm{w}$ toku postępowania sądy nigdy nie zapytały jej o to, czy wie, gdzie aktualnie przebywa jej były mąż. Zdaniem Trybunału zaniechania sądów krajowych były tym mniej usprawiedliwione, że w świetle przepisów krajowych były one zobowiązane do oceny prawidłowości adresu uczestnika postępowania wskazanego przez wnioskodawcę. Mając wszystkie te okoliczności na uwadze, ETPC orzekł, że odmowa uchylenia wyroków zaocznych oparta tylko na argumencie, że dochowano przewidzianej w prawie procedury doręczeń, była nadmiernie formalistyczna, skoro było już wówczas oczywiste, że w trakcie kwestionowanych postępowań skarżący przebywał za granica. Jednocześnie ETPC zauważył, że postępowanie skarżącego także nie było w pełni właściwe, gdyż nie powiadomił on właściwych organów meldunkowych o zmianie swojego miejsca pobytu. Niemniej sankcja w postaci niemożności uchylenia wyroku zaocznego i ponownego rozpatrzenia sprawy była w tym przypadku zbyt daleko idacca.

Odnosząc się jeszcze do kwestii wpływu zachowania strony na ocenę przebiegu postępowania pod kątem zgodności ze standardami wynikającymi z art. 6 ust. 1 Konwencji, należy wskazać, że zarzutu nadmiernego formalizmu nie będzie mogła skutecznie podnieść osoba, która nadużywa prawa do sądu. W doktrynie pojęcie nadużycia prawa do sądu definiuje się jako korzystanie „z uprawnień procesowych w celach innych niż ich przeznaczenie wynikające z celów, którym służy dana procedura, i z jej zasad naczelnych" ${ }^{44}$. Może ono polegać na przykład na wszczynaniu oczywiście bezzasadnych postępowań po to, by sparaliżować pracę sądu lub organu administracji albo uprzykrzyć życie stronie przeciwnej. Co do zasady ETPC zezwala państwom na wprowadzanie pewnych mechanizmów eliminujących przypadki nadużywania prawa do sądu, pod warunkiem, że są one „rzetelnie stosowane i przewidują środki zapewniające, że prawidłowe pozwy będą rozpoznane w odpowiednim postępowaniu" ${ }^{45}$. Co więcej, w sprawie Bock przeciwko Niemcom ${ }^{46}$ ETPC sam odrzucił skargę, w której podnoszony był zarzut naruszenia art. 6 ust. 1 EKPC w związku z przewlekłością postępowania krajowego, uznając, że jest ona oparta na nadużyciu prawa. Skarżący prowadził bowiem postępowanie z wykorzystaniem wszystkich krajowych instancji odwoławczych oraz skargi do ETPC w sprawie o wyjątkowo błahym charakterze, przez co sam przyczyniał się do powstawania przewlekłości.

Uzasadnienie niedochowania pewnych wymogów formalnych może wynikać również z sytuacji osobistej strony. Jeśli zatem ma ona, z przyczyn obiektywnych, ograniczone możliwości skutecznego udziału w postępowaniu sądowym, konieczne może być potraktowanie jej w sposób „łagodniejszy”.

44 Szwast, Szwed (2016): 57.

${ }^{45}$ Hofmański, Wróbel (2010): 296; zob. też: postanowienie ETPC z 20 października 2010 r. w sprawie Toyaksi i inni przeciwko Turcji, skargi nr 43569/08, 5801/09, 19732/09 i 20119/09.

${ }_{46}$ Postanowienie ETPC z 19 stycznia 2010 r. w sprawie Bock przeciwko Niemcom, skarga nr 22051/07. 
Ograniczenie owych możliwości może być spowodowane zwłaszcza niepełnosprawnością intelektualną lub psychiczną. Orzecznictwo ETPC na tym tle jest ubogie, warto jednak zwrócić uwagę na wyrok w sprawie A.N. przeciwko Litwie. Trybunał skrytykował w nim nadmiernie formalistyczne podejście prawników gwarantowanej przez państwo Służby Pomocy Prawnej oraz rządu litewskiego do pism skarżącego, mężczyzny z poważnymi zaburzeniami psychicznymi, wobec którego prowadzono postępowanie o ubezwłasnowolnienie $^{47}$. Co istotne, ETPC odwołał się przy tym do art. 13 Konwencji o prawach osób niepełnosprawnych ${ }^{48}$, zobowiąującego państwa do zapewnienia osobom z niepełnosprawnością dostępu do sądu między innymi przez wprowadzenie odpowiednich dostosowań proceduralnych. Wydaje się, że „łagodniejsze traktowanie" może być jednak konieczne także w przypadku innych kategorii podmiotów, które moga mieć trudności w samodzielnym występowaniu w postępowaniu i zrozumieniu wszystkich wymogów procesowych na przykład ze względu na swój podeszły wiek.

Analizując, czy niedochowanie określonych wymogów formalnych było usprawiedliwione, ETPC bierze pod uwagę także to, czy strona, która takich błędów się dopuściła, była reprezentowana przez profesjonalnego pełnomocnika ${ }^{49}$. Jeśli strona występowała $\mathrm{w}$ postępowaniu samodzielnie, to uzasadnienie niedochowania pewnych wymogów formalnych może wynikać z braku pouczenia jej przez sąd o obowiązujących regulacjach i konsekwencjach ich naruszenia ${ }^{50}$. Podobna konstatacja musi oczywiście dotyczyć sytuacji, w której strona działała w zaufaniu do błędnego pouczenia sądu. W przypadku stron reprezentowanych przez profesjonalnych pełnomocników formułowanie wobec sądu zarzutu nadmiernego formalizmu jest trudniejsze, gdyż jest oczywiste, że od adwokatów czy radców prawnych można wymagać większej staranności i lepszej znajomości zasad procedury. Niemniej nie można zapominać, że odrzucenie środka zaskarżenia wniesionego przez profesjonalnego pełnomocnika w dalszym ciagu stanowi ograniczenie prawa do sądu i z tego względu powinno mieć charakter proporcjonalny, a także być oparte na jasnych i służących realizacji uzasadnionych celów przepisach. Tym samym fakt reprezentacji strony przez pełnomocnika nie oznacza wykluczenia możności podnoszenia zarzutu naruszenia przez sąd zakazu nadmiernego formalizmu, a jedynie stanowi istotną okoliczność uwzględnianą przy ocenie, czy do takiego naruszenia rzeczywiście doszło. Podobnie zresztą sam fakt, że strona działała w postępowaniu samodzielnie, nie może usprawiedliwiać każdego popełnionego przez nią błędu formalnego.

${ }^{47}$ Wyrok ETPC z 31 maja 2016 r. w sprawie A.N. przeciwko Litwie, skarga nr 17280/08: pkt 101-102.

${ }^{48}$ Konwencja o prawach osób niepełnosprawnych, sporządzona w Nowym Jorku dnia 13 grudnia 2006 r., Dz. U. 2012, poz. 1169.

${ }_{49}$ Zob. np. Zubac przeciwko Chorwacji: pkt 117; wyrok ETPC z 28 marca 2019 r. w sprawie Adamkowski przeciwko Polsce, skarga nr 57814/12: pkt 34.

${ }^{50}$ Por. Kunert przeciwko Polsce: pkt 35-37. 


\section{PODSUMOWANIE}

Nadmierny formalizm procesowy, jako szczególny rodzaj ograniczenia prawa do sądu gwarantowanego w art. 6 ust. 1 EKPC, polega na zastosowaniu wobec jednostki nieproporcjonalnych sankcji procesowych z tytułu niedochowania pewnych wymogów formalnych. Tak pojmowany nadmierny formalizm może wynikać zarówno z wadliwego kształtu przepisów krajowych, jak i niewłaściwego sposobu ich zastosowania. Ustaleń w tym zakresie należy dokonywać z uwzględnieniem wszystkich istotnych okoliczności sprawy.

Choć orzecznictwo ETPC na tle omawianego zagadnienia jest mocno kazuistyczne, pozwala ono na ustalenie najważniejszych czynników, które należy brać pod uwagę, dokonując oceny, czy w danym przypadku doszło do niezgodnego z EKPC nadmiernego formalizmu. Po pierwsze, istotne jest to, czy zastosowanie wobec jednostki sankcji procesowych miało wyraźna podstawę w prawie krajowym, a także czy przepisy stanowiące taką podstawę były odpowiednio przewidywalne i czy same w sobie nie ustanawiały one nieproporcjonalnej bariery w dostępie do sądu. Szczególne znaczenie ma to, czy tego rodzaju wymogi formalne służyły uzasadnionym celom, zwłaszcza pewności prawa i zapewnienia prawidłowego funkcjonowania wymiaru sprawiedliwości, co należy oceniać, uwzględniając między innymi szczebel i rodzaj postępowania, w toku którego doszło do rzekomego nadmiernego formalizmu. Po drugie, należy rozważyć, czy teoretycznie uzasadniony przepis, w realiach danej sprawy nie został zastosowany w sposób nadmiernie formalistyczny, przez co stał się nadmierna bariera w dostępie do sądu. Niedochowanie pewnych wymogów formalnych może być bowiem niekiedy uzasadnione (np. brakiem odpowiedniego pouczenia strony występującej bez pełnomocnika procesowego czy jej nieporadnością wynikająca ze stanu zdrowia lub wieku). Istotną okolicznością łagodząca może być także dochowanie przez stronę należytej staranności w toku postępowania, uniemożliwiajace postawienie jej zarzutu niedbalstwa.

Ocena, czy w danym przypadku doszło do naruszenia zakazu nadmiernego formalizmu, a tym samym pogwałcenia art. 6 ust. 1 EKPC, jest więc procesem skomplikowanym i wymagającym uwzględnienia zarówno kształtu krajowych przepisów proceduralnych, jak i szczególnych okoliczności sprawy. Wydaje się jednak, że najważniejszym wnioskiem płynącym z lektury orzecznictwa ETPC jest nie tyle konieczność gruntownego odformalizowania postępowań sądowych, ile nakaz poszukiwania przez państwa pewnej równowagi między prawem dostępu do sądu a dążeniem do zapewnienia efektywności postępowań sądowych. Tym samym przepisy określające wymogi formalne i sankcje z tytułu ich niedochowania nie powinny stosowane przez sądy mechanicznie, lecz w sposób uwzględniający ocenę szczególnych okoliczności konkretnej sprawy.

Marcin Szwed

Uniwersytet Warszawski

m.szwed@uw.edu.pl

https://orcid.org/0000-0002-7692-7043 
Cieślak, S. (2007). Analiza prawnoporównawcza formalizmu postępowania cywilnego - cz. 1. Monitor Prawniczy 12 (wersja elektroniczna).

Hofmański, P., Wróbel, A. (2010). Komentarz do art. 6 EKPC, [w:] L. Garlicki (red.), Konwencja o Ochronie Praw Człowieka i Podstawowych Wolności. Tom: 1: Komentarz do artykułów 1-18. Warszawa: 241-461.

Kościółek, A. (2020). Komentarz do art. 130 Kodeksu postępowania cywilnego, [w:] T. Zembrzuski (red.), Kodeks postępowania cywilnego. Koszty sądowe w sprawach cywilnych. Dochodzenie roszczeń w postępowaniu grupowym. Przepisy przejściowe. Komentarz do zmian. Tom 1-2. WKP 2020 (wydanie elektroniczne).

Pawliczak, J., Wach-Pawliczak, M. (2012). Konstytucyjne granice formalizmu postępowania cywilnego. Monitor Prawniczy 3: 159-165.

Piaskowska, O.M. (2018). Odrzucenie skargi na przewlekłość postępowania cywilnego a limine. Europejski Przegląd Sądowy 9: 19-25.

Szwast, M., Szwed, M. (2016). Nadużycie prawa do sądu w postępowaniu sądowoadministracyjnym. Zeszyty Naukowe Sądownictwa Administracyjnego 6: 52-76.

Zembrzuski, T. (2018). Formalizm procesowy a skutki wadliwego oznaczenia pisma procesowego spełniającego wymagania środka zaskarżenia. Przegląd Sądowy 1: 5-22.

\section{EXCESSIVE PROCEDURAL FORMALISM AS A VIOLATION OF ARTICLE 6(1) OF THE CONVENTION ON HUMAN RIGHTS AND FUNDAMENTAL FREEDOMS}

\section{Sum mary}

All judicial proceedings are inevitably based on the formalized procedures. Procedural provisions pursue many important objectives, such ensuring the effectiveness of proceedings or protecting legal certainty by regulating the competences of procedural bodies and the rights and duties of parties. At the same time, excessive procedural formalism may disproportionately limit the right to court, making access to court illusory. Within the framework of the European Convention on Human Rights, the permissible limits of procedural formalism are set by Article 6(1). The European Court of Human Rights, assessing whether excessive formalism has occurred in a given case, examines whether relevant formal requirements served a legitimate purpose, in particular legal certainty and proper administration of justice, and did not lead to a disproportionate restriction of the right of access to court. This assessment is made on the basis of all relevant circumstances of the case, such as the stage at which the proceedings were terminated, the type of proceedings, the party's due diligence, the existence of circumstances justifying failure to comply with a formal requirement or the fact that the party was represented by a professional representative. Therefore, not only the content of national provisions is important, but also the manner of their application by courts.

Keywords: right to court; excessive formalism; limitations of the right to court; ECtHR; Article 6 of ECHR 